EPJ Web of Conferences 92,02119 (2015)

DOI: $10.1051 /$ epjconf/ 20159202119

(C) Owned by the authors, published by EDP Sciences, 2015

\title{
Various methods to improve heat transfer in exchangers
}

\author{
Zitek Pavel $^{1, \mathrm{a}}$, Valenta Vaclav ${ }^{1}$ \\ ${ }^{1}$ UWB in Pilsen, Department of Power System Engineering, Univerzitni 8, 30614 Pilsen, Czech Republic
}

\begin{abstract}
The University of West Bohemia in Pilsen (Department of Power System Engineering) is working on the selection of effective heat exchangers. Conventional shell and tube heat exchangers use simple segmental baffles. It can be replaced by helical baffles, which increase the heat transfer efficiency and reduce pressure losses. Their usage is demonstrated in the primary circuit of IV. generation MSR (Molten Salt Reactors). For high-temperature reactors we consider the use of compact desk heat exchangers, which are small, which allows the integral configuration of reactor. We design them from graphite composites, which allow up to $1000^{\circ} \mathrm{C}$ and are usable as exchangers: salt-salt or salt-acid (e.g. for the hydrogen production). In the paper there are shown thermo-physical properties of salts, material properties and principles of calculations.
\end{abstract}

\section{Introduction}

At the University of West Bohemia, the Department of Power Engineering, we work on a selection of efficient heat exchangers. The most frequent in the operation are so-called tube and shell exchangers (approx. $40 \%$ on the European market). These can be improved by helical baffles. This improvement was suggested by employees of Research Institute of Chemical Equipment Brno in 1980s. Czech literature does not mention it; references and a description can be found in the G.F. Hewitt's book [1]. Therefore we will show properties and possibilites of calculations of those shell and tube exchangers.

Other perspective exchangers are compact plate exchangers, which are small and allow an integral fuel assembly for the generation IV reactors. We will use graphite composites as construction material for hightemperature reactors. This material will allow to design both salt-salt and salt-acid exchangers for production of hydrogen.

\section{Shell and tube exchangers}

Conventional shell and tube exchangers use simple segmental baffles; helical baffles, which will increase heat transfer efficiency and reduce pressure losses, can replace them.

Baffles design of helixchanger are show figure 1, figure 2. Comparison of baffle type is in figure 3.

Why to use Helixchander anywhere it is possible is shown by an example for retrofit in oil hydrogeneration refining (crude oil preheating $1 \mathrm{MW}, 90 \mathrm{t} / \mathrm{hr}$ ). Comparison segmental baffles $(\Delta \mathrm{p}=44 \mathrm{kPa})$ and helical baffles
$(\Delta \mathrm{p}=17 \mathrm{kPa})$. Result: $60 \%$ reduction of operating costs, $6.3 \%$ reduction of total costs [3].

Comparative performance is in figure 4.

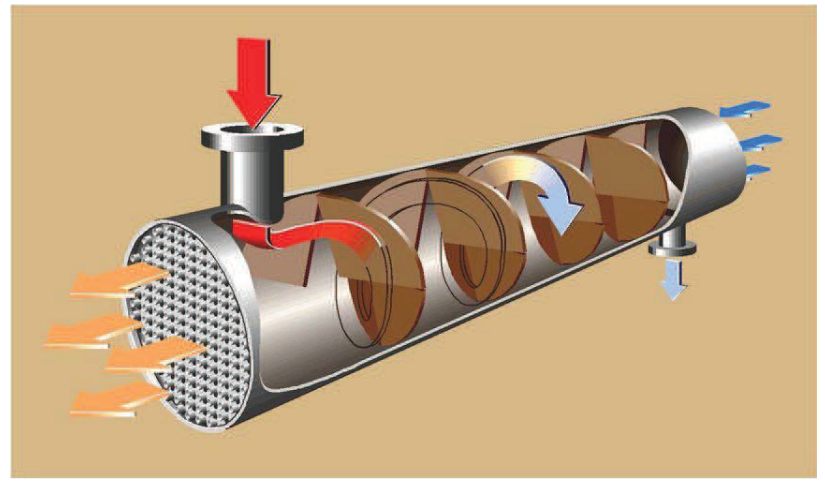

Figure 1 Helixchanger

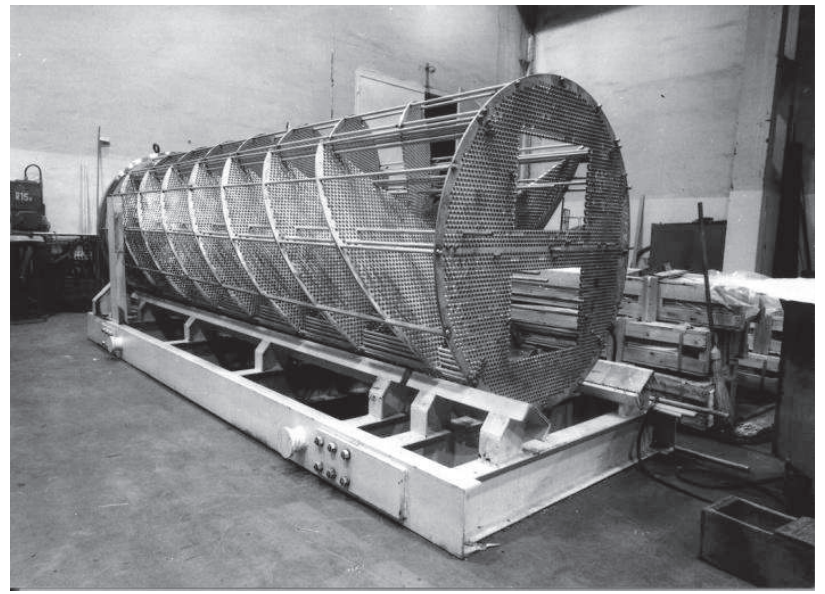

Figure 2 Helical baffles

\footnotetext{
a Corresponding author: zitek@kke.zcu.cz
} 


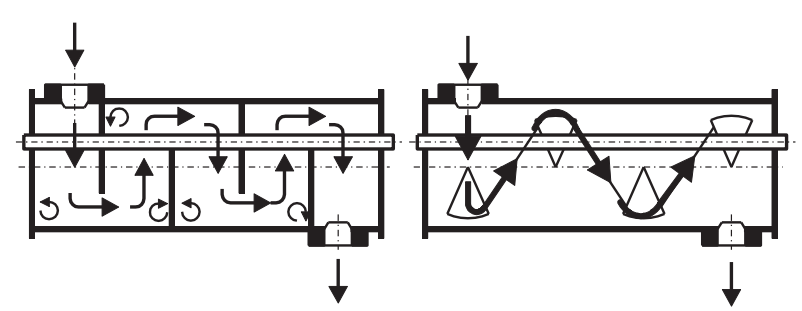

Figure 3 Comparison of segmental and helical baffles

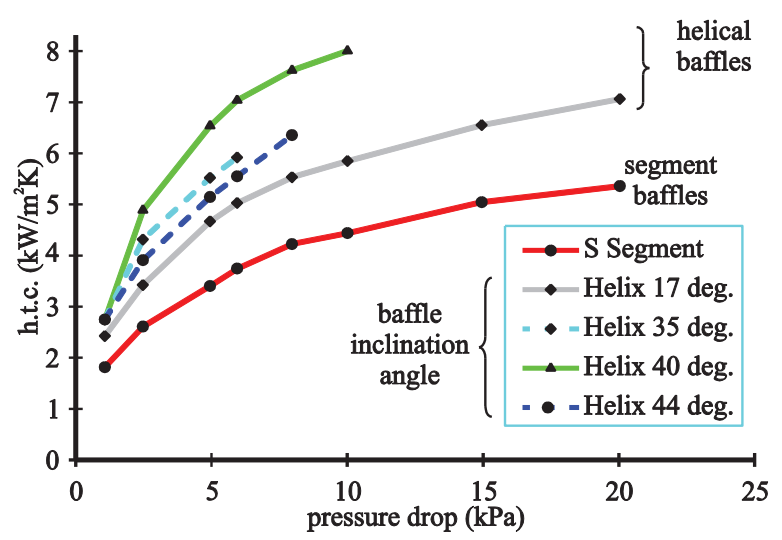

Figure 4 Comparative performance

Helical baffles with an inclination angle 40 deg have maximum efficiency in heat transfer and minimal pressure drop.

A helixchanger offers the following general advantages:

- increased heat transfer rates/pressure drop ratio

- reduced bypass effects

- reduced shell - side fouling

- prevention of flow-induced vibration

- reduced maintenance

Other new forms of a shell and tube exchanger:

a) ROD baffle exchanger (see figure 5)

- Overcoming the problem of flow-induced vibration

- Decreased pressure drop and fouling

b) Twisted tube exchanger (see figure 6 and [2] for detail)

- Twisted tubes support each other in the tube bundle assembly.

- Approximately $40 \%$ higher h.t.c. than conventional exchanger the same pressure drop.

- Metal belts tightly strap the tubes together.

- Metal shroud around the bundle eliminates bypass flow between the shell and the bundle.

c) Corrugated tube exchanger.

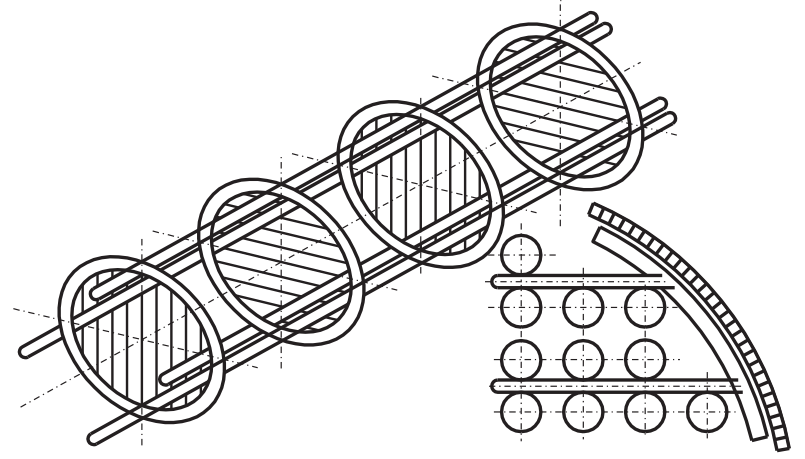

Figure 5 ROD baffle exchanger

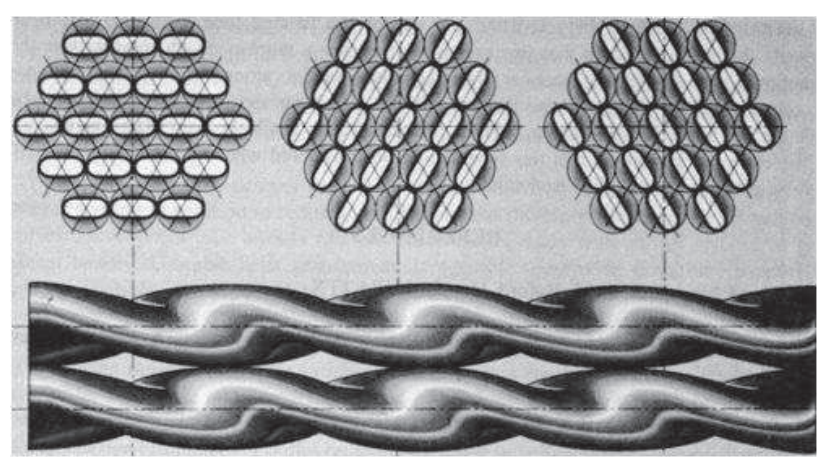

Figure 6 Twisted tube

For the calculation, a general expression for the Nusselt number with a correction is used.

Heat transfer inside the tube space.

a) For a tube of a circular cross section and laminar flow, the Hausen relation is valid:

$$
=\left[\frac{0,19 \cdot\left(R e_{1} \cdot P r_{1} \cdot y_{1}\right)^{0,8}}{1+0,117 \cdot\left(R e_{1} \cdot P r_{1} \cdot y_{1}\right)^{0,457}}+3,65\right] \cdot y_{2},
$$

where the coefficient $y_{1}$ takes into account the influence of the working substance inlet into the tube

$$
y_{1}=\frac{d_{1}}{l_{t}}
$$

and the correction factor $y_{2}$ takes into account the change of the fluid substance properties in the boundary layer

$$
y_{2}=\left(\frac{P r_{1}(T)}{P r_{1 w}\left(T_{w}\right)}\right)^{0,11}
$$

where

$T(K) \quad$ is average temperature of fluid

$T_{w}(K) \quad$ is temperature of wall

b) Gnielinsky relation satisfies transition and turbulent flow $(\operatorname{Re}>2320)$ in a circular cross section tube:

$$
\begin{gathered}
N u_{1}= \\
=\frac{x_{5} \cdot\left(R e_{1}-1000\right) \cdot P r_{1}}{1+12,7 \sqrt{x_{5}}\left(\operatorname{Pr}_{1}^{2 / 3}-1\right)} \cdot\left(1+y_{1}^{2 / 3}\right) \cdot y_{2}, \\
x_{5}=\frac{1}{8} \cdot\left(1,82 \cdot \log R e_{1}-1,64\right)^{-2},
\end{gathered}
$$
flow. 
Heat transfer in the space between tubes. (see Bell in [1])

Correction for segmental baffle:

$$
\begin{gathered}
N u_{2}=\left[0,3+\sqrt{N u_{\text {lam }}^{2}+N u_{\text {turb }}^{2}}\right] \\
\cdot y_{2} \cdot y_{3} \cdot y_{4} \cdot y_{5} \cdot y_{6} \cdot y_{7} \cdot y_{8} \\
N u_{\text {lam }}=0,664 \sqrt{R e_{2}} \cdot \sqrt[3]{P r_{2}} \\
N u_{\text {turb }}=\frac{0,037 \cdot R e_{2}^{0,7} \cdot P r_{2}}{1+2,443 \cdot R e_{2}^{-0,1} \cdot\left(P r_{2}^{2 / 3}-1\right)} .
\end{gathered}
$$

Corrections for helically baffled HE:

$$
\begin{gathered}
N u_{2}=0,62 \cdot\left[0,3+\sqrt{N u_{\text {lam }}^{2}+N u_{\text {turb }}^{2}}\right] \cdot y_{2} . \\
\cdot y_{3} \cdot y_{4} \cdot y_{7} \cdot y_{8} \cdot y_{9} \cdot y_{10}
\end{gathered}
$$

Correction factors: (see detail in [3])

$y_{2} \quad$ for thermo-physical properties

$y_{3}$ for scale-up from a single tube row to a bundle of tubes

$y_{4}$ for an adverse temperature gradient

$y_{5}$ for baffle window cross-flow penetration

$y_{6}$ for baffle-to-shell and tube-to-baffle leakage stress

$y_{7} \quad$ for bundle-to-shell bypass stress

$y_{8} \quad$ for baffle sparing in inlet and outlet sections

$y_{9}$ factor accounting for the change in the cross-flow characteristics of the exchanger

$y_{10}$ turbulence enhancement factor

We have chosen the MSBR exchanger (Molten Salt Breeder Reactor - $1000 \mathrm{MWel}$ ); see Figure 7, for the use of helical baffles in primary exchangers in the new nuclear reactors of the generation IV projects. It is a counter-flow exchanger with the output of 563 MWth. This study uses all its dimensions. Working temperature $600-720^{\circ} \mathrm{C}$. The advantage of this construction solution is the fact that heat-exchanging tubes are bent in the $\mathrm{L}$ shape, which allows compensating the thermal expansion of the tubes. [5].

2 different primary salts were chosen for analyses:

a) Primary salt has a composition of $\mathrm{LiF}-\mathrm{BeF}_{2}-\mathrm{ThF}_{4}$ $\mathrm{UF}_{4}(71.7-16-12-0.3 \% \mathrm{~mol})$, secondary salt NaF$\mathrm{NaBF}_{3}(8-92 \% \mathrm{~mol})$, for MSR working in a thorium cycle.

b) Primary salt with a composition of $\mathrm{Li} \mathrm{F}-\mathrm{BeF}_{2}-$ $\mathrm{NaF}-\mathrm{UF}_{4}(14.9-26.8-57.8-0.6 \% \mathrm{~mol})$ for MSR working in a transmuter mode for a combustion of plutonium and higher actinides from burnt-up fuel of classic nuclear reactors. (The salt assures the solubility of $\mathrm{PuF}_{3} \quad 2.0 \mathrm{~mol}^{\%}$ during $600{ }^{\circ} \mathrm{C}$.)

Tube dimensions:

$$
\begin{array}{ll}
\text { inner diameter } & \mathrm{d}_{\text {in }}=0.01(\mathrm{~m}) \\
\text { outside diameter } & \mathrm{d}_{\text {out }}=0.0118(\mathrm{~m}) \\
\text { number of tubes } & \mathrm{n}_{\mathrm{t}}=5549[1] \\
\text { number of runs } & \mathrm{n}_{\mathrm{ch}}=1
\end{array}
$$

The tubes are located with a $0.0123 \mathrm{~m}$ step on 31 concentric tracks with a $0.0182 \mathrm{~m}$ track step.

Exchanger shell dimensions:

$$
\mathrm{D}_{\text {out }}=1.657(\mathrm{~m})
$$

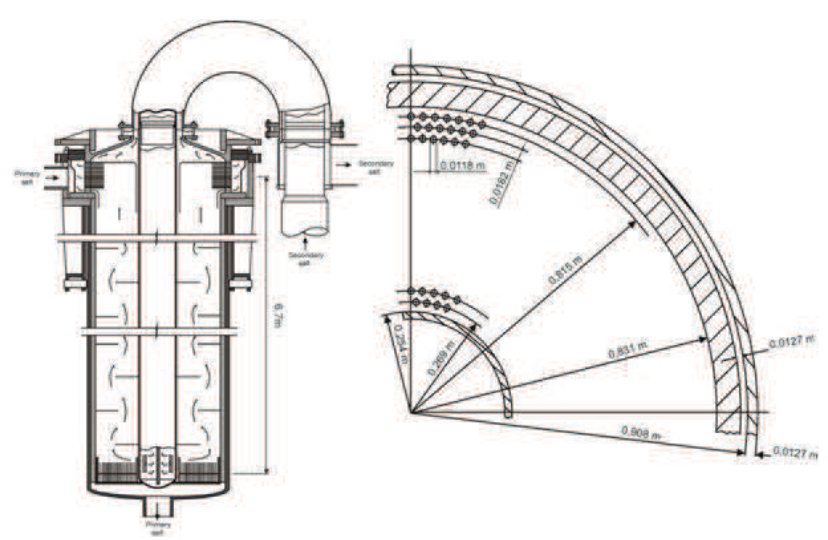

Figure 7 Exchanger for MSBR 1000

\section{Compact Heat Exchangers}

Characteristic features:

- High heat transfer coefficient and large surface area with a small footprint.

- Viable cost-effective alternatives.

- Heat transfer area density in excess of $700 \mathrm{~m}^{2} / \mathrm{m}^{3}$.

Advantages:

- Possible pure counter-flow configuration.

- Higher heat transfer area density can be further increased using enhancement $\Rightarrow$ compactness.

- Benefit:

a) for given heat duty $Q$ a smaller temperature difference can be required.

b) for given mean temperature difference $\Delta T_{m}$ heat duty $Q$ can be higher.

- We can determine an optimum design and dimensions of a plate type heat exchanger.

We will assume for the calculation, that we have available pressed plates from graphite composites, e.g. manufactured by the technology described in details in [9] and we will create an exchanger core from them. As illustrated in the picture, we can simply divide the exchanger core to elements symmetrical according to the axis, and then solve those elements by a plate with ribs from both sides. The height of ribs equals to $b / 2$, the depth of a wall is $d$.
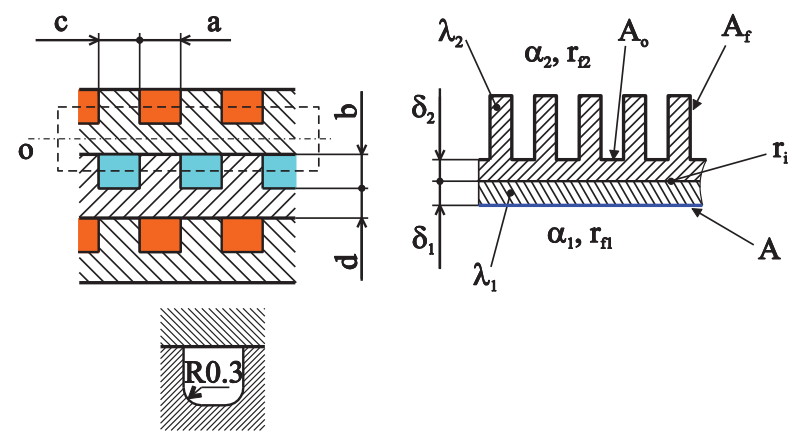

Figure 8 Heat exchanger core scheme 
We consider appropriate to remind the following facts for plate exchangers.

Based on the size of the Reynold number, we distinguish three basic regimes:

1. Laminar flow, $\mathrm{Re} \leq \mathrm{Re}_{\text {krit }}$

2. Transition flow, $\operatorname{Re}_{\text {krit }}<\operatorname{Re}<10^{5}$

3. Turbulent flow, $\operatorname{Re}>10^{5}$

In the transition area, where $\mathrm{Re}_{\text {krit }}<\mathrm{Re}<10^{5}$, the flow character is not clearly defined. Based on the conditions, it can be laminar, turbulent, or both types can alternate. It depends on the fluid inlet method into the channel. When the inlet is realized in the shape of a confuser with smooth walls, the laminar flow in the channel can remain until the higher values of Re. If the inlet into the channel is not shaped and the fluid bypasses edges, the turbulent flow can appear closely above $\mathrm{Re}_{\text {krit }}$. The channel vibrations, which initiate the turbulent flow regime, have a similar influence. Jumping between both flow regimes can appear in the transition area. So-called intermittency introduces itself here, which defines the turbulent flow proportion and can assume values from the interval $<0-1>$. The upper limit is not firmly set and can change according to circumstances.
Laminar

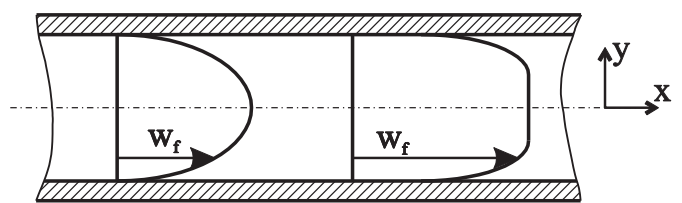

Figure 9 Velocity profiles during laminar and turbulent flow

The critical Reynold number $\mathrm{Re}_{\text {krit }}$ is defined experimentally, and it varies for different shapes of the channel cross section. For a circular channel, $\mathrm{Re}_{\text {krit }}=2300$ is usually assumed. Table 1 shows values $\mathrm{Re}_{\text {krit }}$ for a rectangular channel [21], with various side ratios $b / a$, and for a smooth channel inlet, i.e. a confusor assisted one, or for a sharp inlet, when the fluid bypasses the edge. It is apparent that the inlet version has a substantial influence on the flow pattern.

Table 1 Values $\mathrm{Re}_{\text {krit }}$ for a rectangular channel

\begin{tabular}{|c|c|c|c|}
\hline $\begin{array}{c}\text { Rectangular } \\
\text { channel }\end{array}$ & $\begin{array}{c}\text { side ratio } \\
b / a\end{array}$ & inlet & $\mathrm{Re}_{\text {krit }}$ \\
\hline \multirow{4}{*}{ b } & $1: 1$ & smooth & 4300 \\
\cline { 2 - 4 } & $1: 1$ & sharp & 2200 \\
\cline { 2 - 4 } DIIIIIII a & $3: 1$ & smooth & 6000 \\
\cline { 2 - 4 } & $5: 1$ & smooth & 7000 \\
\cline { 2 - 4 } & $5: 1$ & sharp & 2500 \\
\cline { 2 - 4 } & $10: 1$ & smooth & 4400 \\
\cline { 2 - 4 } & $10: 1$ & sharp & 2500 \\
\hline
\end{tabular}

If the fluid enters the channels with a constant speed along the cross section, there develops a velocity and temperature profiles in so-called inlet length with a size of $X=\max \left(X_{w}, X_{t}\right)$, where $X_{w}$ is a hydrodynamic stabilization length, $X_{t}$ is temperature stabilization length. So that we differentiate the inlet flow area $(x<X)$ and a fully evolved flow area $(x>X)$.

The event of a constant inlet speed can appear when a chamber with a relatively large cross section, where there is a low speed, prepends the channel. When the fluid inlet with already evolved velocity profile is required, a continuous inlet in the shape of a confuser goes in production, or it extends before the beginning of the heat transfer section. The figure 10 illustrates the hydrodynamic and temperature stabilization length, depending on $P r$ in such a case, when the heat transfer begins at the channel entry.

Prandtl criteria can also be understood as a ratio of a molecular momentum and thermodiffusion. When $\operatorname{Pr}>1$, momentum diffusion prevails thermodiffusion, the speed boundary layer forms faster than the temperature one, and therefore the hydrodynamic stabilization length is smaller than the temperature one. When $\operatorname{Pr}<1$ it is a vice versa case.

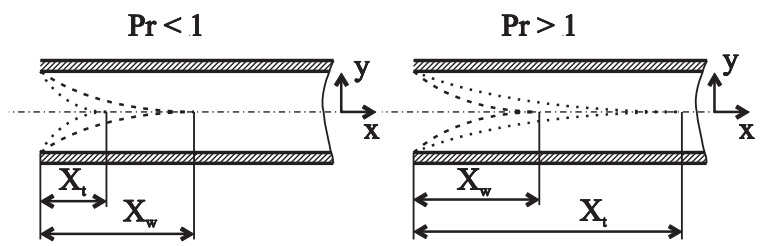

Figure 10 Hydrodynamic and temperature stabilization length depending on the Prandtl criteria

The following relations define an approximate value of hydrodynamic and temperature stabilization length for a laminar flow:

$$
\begin{aligned}
& X_{w} \approx 4 \cdot 10^{-2} \cdot \operatorname{Re} \cdot D \quad(m), \\
& X_{t} \approx 10^{-2} \cdot \operatorname{Pr} \cdot D \cdot \operatorname{Re}(m),
\end{aligned}
$$

and for a turbulent flow

$$
X_{w} \cong X_{t} \cong 10 \cdot D \quad(m)
$$

A flow in non-circular cross sections provides different shapes of velocity and temperature profiles than a flow in a circular channel, and therefore the heat transmission coefficient will be different as well. It is evident that the heat transmission coefficient will significantly change along the perimeter of the channel. Due to this fact, the values of calculated heat transfer coefficient are considered average over perimeter of the channel.

An equivalent hydraulic diameter is considered characteristic in relations for non-circular cross sections:

$$
D_{H}=\frac{4 \cdot A_{k}}{O_{k}},
$$

where
$D_{H} \quad\left(m^{2}\right)$
$A_{k} \quad\left(m^{2}\right)$
equivalent hydraulic diameter
$O_{k}(m)$
is the area of wet cross section
is perimeter of wet cross section

We can use the above-mentioned relations for circular cross sections with a small error for turbulent flow, with a difference of incorporating the hydraulic diameter $D_{H}$ in the criteria.

For laminar flow, where velocity and temperature profiles are significantly shaped, a simple use of relations 
for circular cross section with incorporated hydraulic diameter $D_{H}$ would be affected by a large error. We can specify it by multiplying such a prepared relation by a quotient:

$$
\frac{N u_{\infty}^{\text {rectangular }}}{N u_{\infty}^{\text {circle }}}
$$

where

$N u_{\infty}^{\text {rectangular }}$ is a value of Nusselt number for an evolved flow in a rectangular channel, see table 2 .

$\mathrm{Nu}$ circle is a value for an evolved flow for the case with a constant temperature of a channel wall $\left(N u_{\infty}^{T}=3.66\right)$ or with a constant heat flux in a wall $\left(N u_{\infty}^{q}=4.36\right)$.

Table 2 Values $\boldsymbol{N} \boldsymbol{u}_{\infty}^{T}$ a $\boldsymbol{N} \boldsymbol{u}_{\infty}^{\boldsymbol{q}}$ for evolved flow in a rectangular channel ( $\mathrm{T}$... constant temperature, q ... constant heat flux)

\begin{tabular}{|c|c|c|c|}
\hline $\begin{array}{c}\text { Rectangular } \\
\text { channel }\end{array}$ & $\begin{array}{c}\text { side ratio } \\
b / a\end{array}$ & $N u_{\infty}^{T}$ & $N u_{\infty}^{q}$ \\
\hline \multirow{4}{*}{ b } & 1 & 2.98 & 3.61 \\
\cline { 2 - 4 } & 4.3 & 3.08 & 3.73 \\
\cline { 2 - 4 } & 2 & 3.39 & 4.12 \\
\cline { 2 - 4 } |IIIIIIIIA a & 3 & 3.96 & 4.79 \\
\cline { 2 - 4 } & 4 & 4.44 & 5.33 \\
\cline { 2 - 4 } & 8 & 5.60 & 6.49 \\
\cline { 2 - 4 } & $\infty$ (plates) & 7.54 & 8.23 \\
\hline
\end{tabular}

The following correlations to calculate the Nusselt number for the circular cross section channel were used for the calculations mentioned hereinafter:

- We will use the following simplified expressions

[24] for laminar flow $(R e<2200)$ :

$$
N u_{0-x}^{q d}=1.953 \cdot x_{*}^{\frac{1}{3}} \quad \text { pro } x_{*}<0.03
$$

$$
N u_{0-x}^{q d}=4.364+\frac{0.0722}{x_{*}} \quad \text { pro } x_{*}>0.03
$$

The equation form is determined by the Graetz number, the reciprocal ratio of which, marked as $x_{*}$, determines the used equation

$$
\begin{gathered}
\mathrm{x}_{*}=\frac{1}{\mathrm{Gz}_{\mathrm{H}}}, \\
\mathrm{Gz}_{\mathrm{H}}=\operatorname{Re} \cdot \operatorname{Pr} \cdot \frac{D_{H}}{H} .
\end{gathered}
$$

The channel length $H$ is identical for both flows.

- The relation [Hausen] applies for the transition area $\left(2200<\operatorname{Re}<10^{4}\right)$ :

$$
N u=0.116 \cdot\left(\operatorname{Re}^{\frac{2}{3}}-125\right) \cdot \operatorname{Pr}^{\frac{1}{3}} \cdot\left(\frac{\mu}{\mu_{w}}\right)^{0.14}
$$

- The relation [Sieder] applies for the turbulent flow $\left(10^{4}<\operatorname{Re}<5 \cdot 10^{4}\right)$ :

$$
N u=0.027 \cdot \operatorname{Re}^{\frac{4}{5}} \cdot \operatorname{Pr}^{\frac{1}{3}} \cdot\left(\frac{\mu}{\mu_{w}}\right)^{0.14}
$$

where

$\mu \quad$ is the dynamic viscosity inside the flow

$\mu_{w} \quad$ is the dynamic viscosity by the wall, i.e. under the wall temperature $T_{w}$

As a primary fluoride salt $\mathrm{LiF}-\mathrm{BeF}_{2}$ is used, secondary fluoride salt is $\mathrm{NaF}-\mathrm{NaBF}_{4}$.

\section{The impact of quantities on the exchanger parameters}

As an initial was chosen an exchanger, which core has a width $S=1 \mathrm{~m}$, a height $v=0,8 \mathrm{~m}$ and a length $H=1.2 \mathrm{~m}$. The channel dimensions are $a=1.5 \mathrm{~mm}$ and $c=1.5 \mathrm{~mm}$, the plate thickness $b=1.5 \mathrm{~mm}$ and $d=1.5 \mathrm{~mm}$. The hot flow temperature gradient is firmly set at $\Delta T_{H}=100^{\circ} \mathrm{C}$, the input temperature of hot flow is $1000{ }^{\circ} \mathrm{C}$. The temperature outlet $Q=50 \mathrm{MW}$ was chosen, which can be reached at the hot mass flow of $\dot{m}_{H}=214 \mathrm{~kg} / \mathrm{s}$. The cold mass flow was chosen to be at $\dot{m}_{C}=300 \mathrm{~kg} / \mathrm{s}$, during which the temperature gradient is approximately $\Delta T_{C}=110^{\circ} \mathrm{C}$.

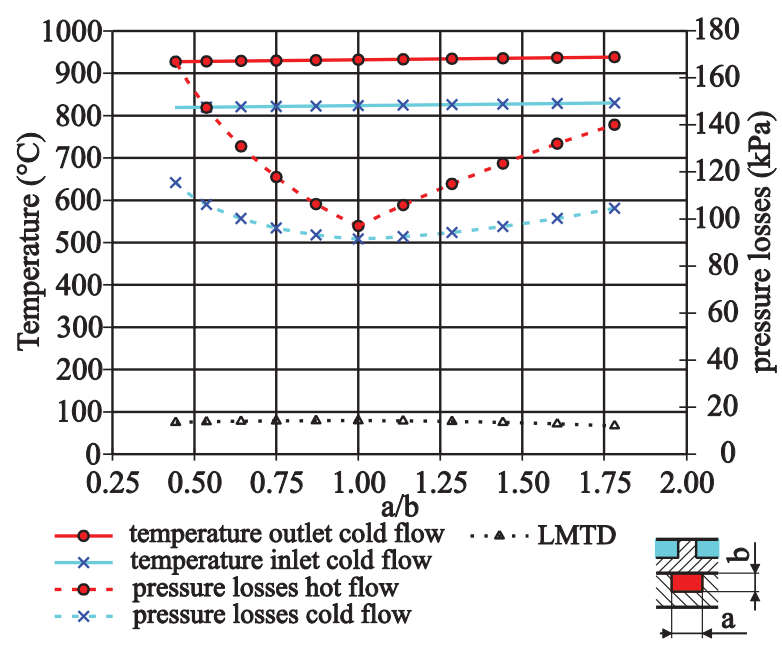

Figure 11 Dependence of cold flow temperatures and pressure losses on the side ratio of the channel with a constant cross section of $2,25 \mathrm{~mm}^{2}$ at $\mathrm{Q}=50 \mathrm{MW}$

Figure 11 illustrates how the exchanger parameters change when considering a rectangle channel with different ratio of sides $a / b$, yet with a constant area of the cross section $A^{\prime}=2,25 \mathrm{~mm}^{2}$. The total core dimensions and the heat output remain unchanged. From the heat transmission, a higher ratio of $a / b$ is more beneficial, as the ratio of the heat transfer surface of the bare plate increases too, to the detriment of the heat transfer surface of the ribs. Moreover, the ribs become relatively shorter, their efficiency increases, and so does the total efficiency of the heat transfer surface indeed. From the point of view of pressure losses, the square channel is the most suitable, when the proportion of the perimeter towards the cross section area is the smallest. A 
hot channel with a laminar flow demonstrates a more considerable dependence of a pressure loss.

At figure 12 there is a graph of the dependence of the exchanger parameters on the length of the square channel side. The total dimensions remain unchanged. It is evident that the heat parameters grow with a decreasing size of the channel. It is determined by a growing heat transfer surface, a growing flow speed, and by a decreasing hydraulic diameter as well as by a growth in heat transmission coefficients. The exchanger's pressure losses considerably grow due to the same reasons.

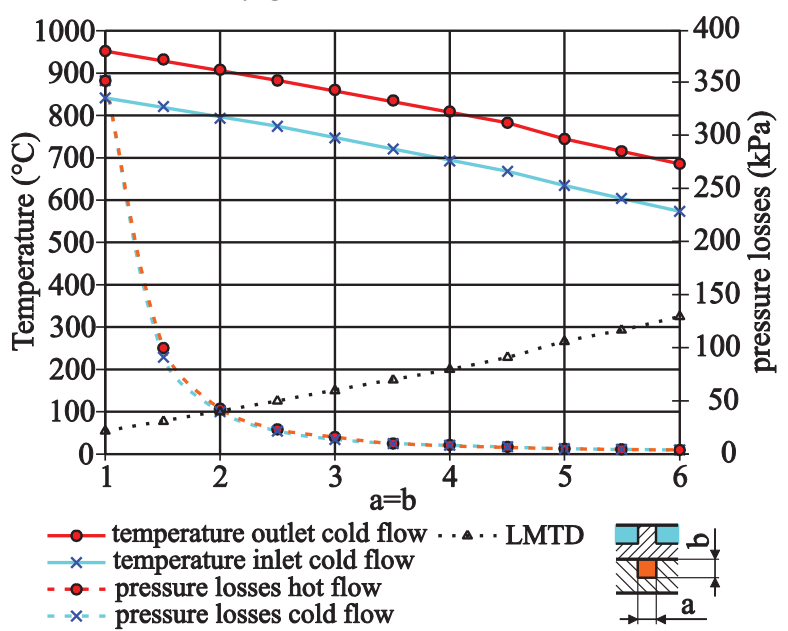

Figure 12 Dependence of cold flow temperatures and pressure losses on the side length of the square channel at $\mathrm{Q}=50 \mathrm{MW}$

Figure 13 shows the dependence of the exchanger parameters on the channel length. Other values remain the same. The growth of heat parameters is quite significant for small lengths. For the lengths bigger than 3 $\mathrm{m}$, temperatures are, in fact, constant. Pressure losses grow linearly with the channel length.

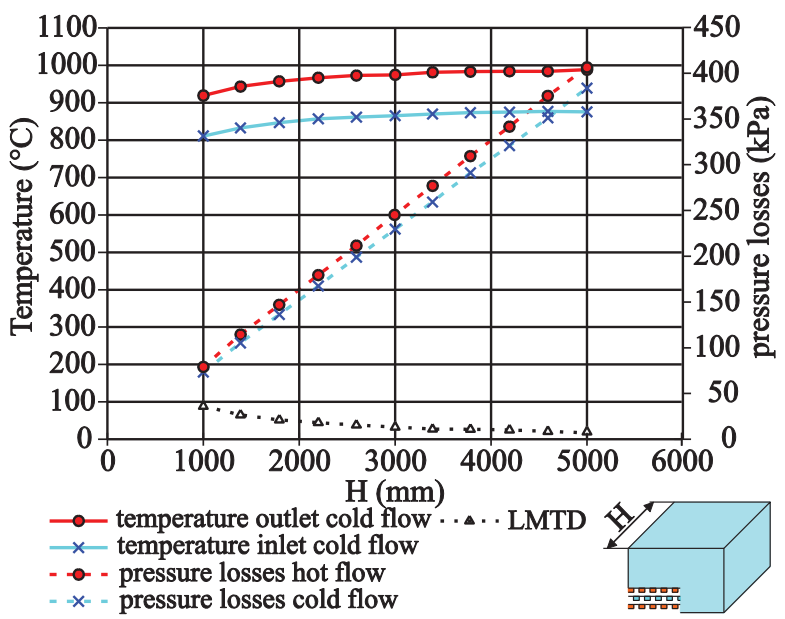

Figure 13 Dependence of cold flow temperatures and pressure losses on the channel length $\mathrm{H}$ at $\mathrm{Q}=50 \mathrm{MW}$

The thickness of the composite material, which is used for the production of the exchanger, depends on the material production technology and the strength requirements for the exchanger core. The figure 14 shows the dependence of the exchanger parameters on the composite thickness. It is dimensions $c, d$. The heat transfer surface must decrease at constant outside dimensions of the core. The growth of heat transmission coefficients influenced by the reduction of the cross section area of the exchanger does not manage to balance this fact out and the cold flow temperatures must decrease. An inductive thermal resistance of walls and ribs increases along with the composite thickness. In addition, pressure losses of the exchanger increase due to the similar reasons.

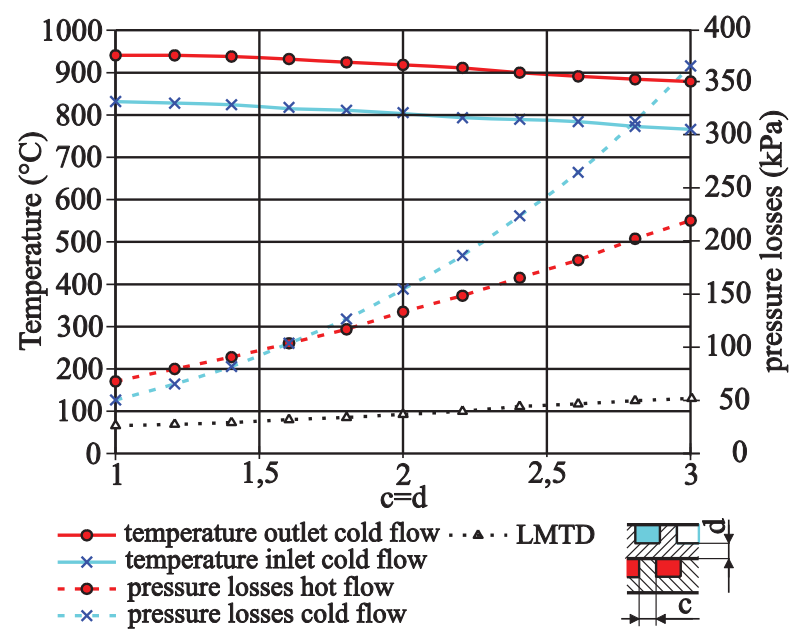

Figure 14 Dependence of cold flow temperatures and pressure losses on the composite thickness at $\mathrm{Q}=50 \mathrm{MW}$

Graphite heat conductivity, and therefore a graphite composite as well, is strongly dependant on the operation temperature and production technology. The figure 15 illustrates the dependence of the exchanger parameters on the composite heat conductivity. A more meaningful effect demonstrates only for values lower than $\lambda_{\text {komp }}=40 \mathrm{~W} / \mathrm{m} \cdot \mathrm{K}$. The composite should not get in this area under such set temperatures.

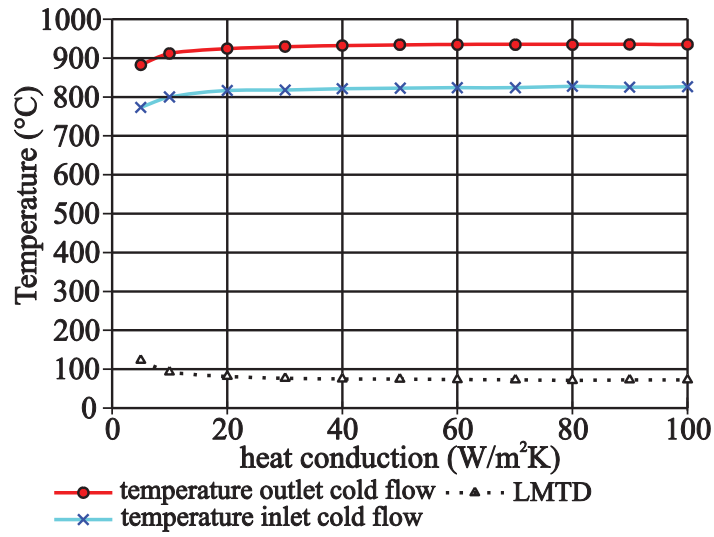

Figure 15 Dependence of cold flow temperatures on the composite heat conductivity at $\mathrm{Q}=50 \mathrm{MW}$

Figure 16 shows the dependence of the exchanger parameters on the cold flow mass flow. Other parameters remain unchanged. Based on the behaviour of parameters, the transition into the turbulent flow regime in the cold channel is well noticeable, which has a positive influence on the heat transition coefficients, but at the same time, the pressure loss grows. The cold flow temperature gradient decreases with higher mass flow. Thus, it is possible to adjust the exchanger parameters to 
the requirements of the technology, which consumes heat from the cold flow.

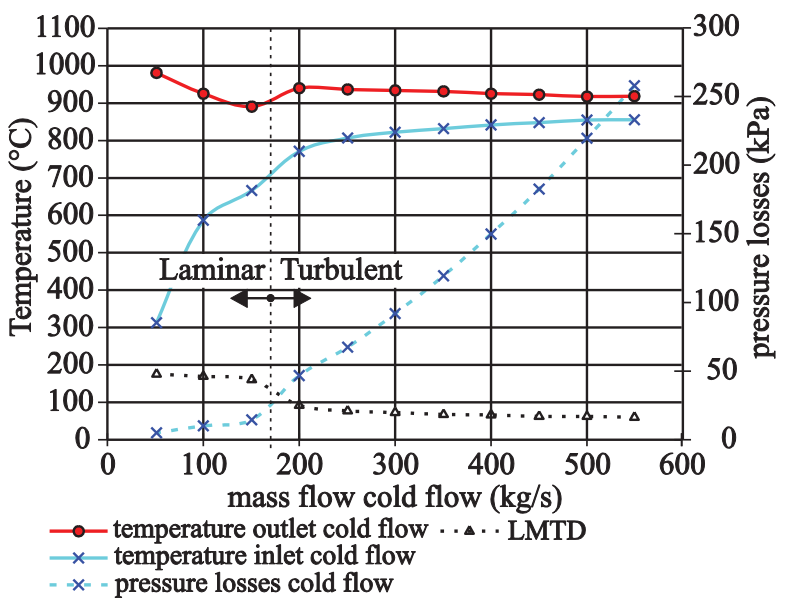

Figure 16 Dependence of cold flow temperatures and pressure losses at the mass flow at $\mathrm{Q}=50 \mathrm{MW}$

The figure 17 illustrates the dependence of cold flow temperatures, hot flow pressure loss and heat power of the exchanger on the hot flow mass flow. In this case, the cold flow mass flow has a constant value $\dot{m}_{C}=100 \mathrm{~kg} / \mathrm{s}$. Both flows are laminar flows in the illustrated extent, and pressure losses are low. This is a case when low values of the exchanger pressure losses are required.

Figure 18 illustrates the same dependences as the previous Figure 17, however, the cold flow mass flow is set higher at $\dot{m}_{C}=400 \mathrm{~kg} / \mathrm{s}$, and moreover, it considers smaller channel and material dimensions $a=b=c=d=1 \mathrm{~mm}$. This method results in substantially higher power but also pressure losses. This is a case when a high exchanger heat power is required.

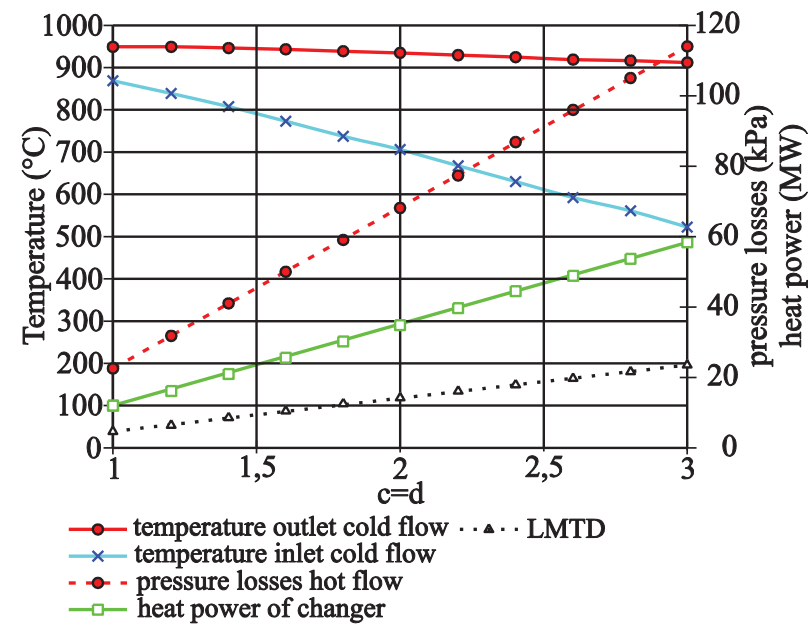

Figure 17 Dependence of cold flow temperatures, hot flow pressure loss and heat power of the exchanger on the hot flow mass flow at $\dot{m}_{C}=100\left(\mathrm{~kg} \cdot \mathrm{s}^{-1}\right)$

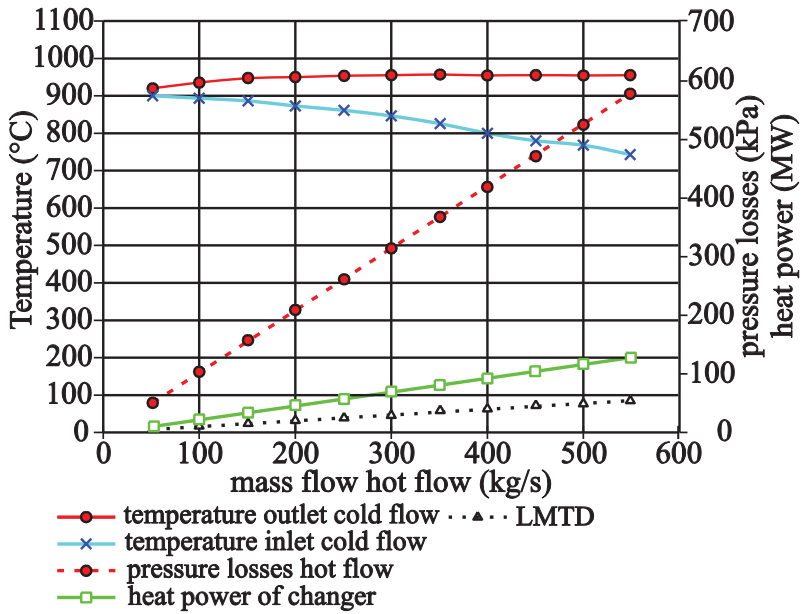

Figure 18 Dependence of cold flow temperatures, hot flow pressure loss and heat power of the exchanger at

$$
\dot{m}_{C}=400\left(\mathrm{~kg} \cdot \mathrm{s}^{-1}\right)
$$

\subsection{Check calculation performed by the FLUENT code}

To start with, it is necessary to say that a calculation by the FLUENT program applies to the exchanger core only; the component, which secures the inlet of the heat transfer fluid from the connection point of the exchanger to its core, is not modelled. The way that fluids enter channels, which depends on the entry part construction set up; can have a large impact on the flow behaviour in channels. Especially for the variant, when a fluid flows in the transition regime (e.g. $\operatorname{Re}_{\mathrm{C}}=3860$ ) in the cold channel. An inlet velocity profile considers having a constant speed after a cross-section, which presents a significant simplification of the reality.

A calculation model description [19, 22].

A simple and regular core design of the exchanger allowed using marginal conditions of Symmetry and Periodicity types, which resulted in an acceptable size of the calculated model.

The Symmetry marginal condition defines zero values of derivatives of all calculated quantities along the normal line of the edge wall. Such conditions appear to be on every vertical plane passing through a longitudinal axis of any channel.

The Periodicity marginal condition is determined for two identical walls and defines the same values of calculated quantities in nodes of the same position. Such conditions appear to be on every two parallel horizontal planes, whose distance equals to the double of vertical pitch of channels.

Figure 19 shows the front part of the model and the use of marginal conditions Symmetry and Periodicity. 


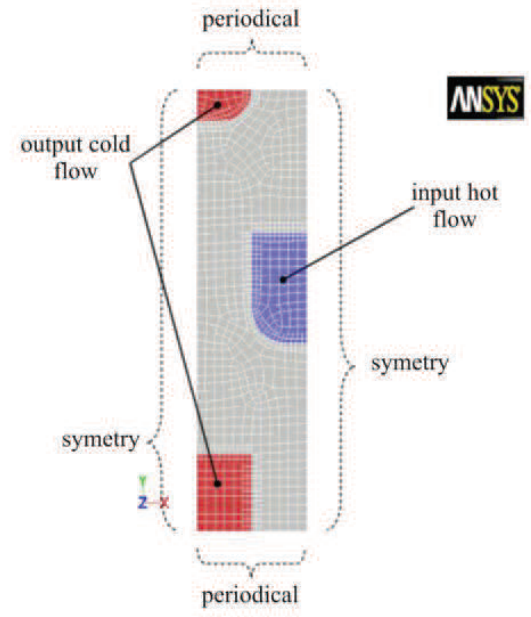

Figure 19 Front wall of the calculated model with marked-up marginal conditions of Symmetry and Periodicity types

We are presenting the following pictures from the FLUENT code outputs:

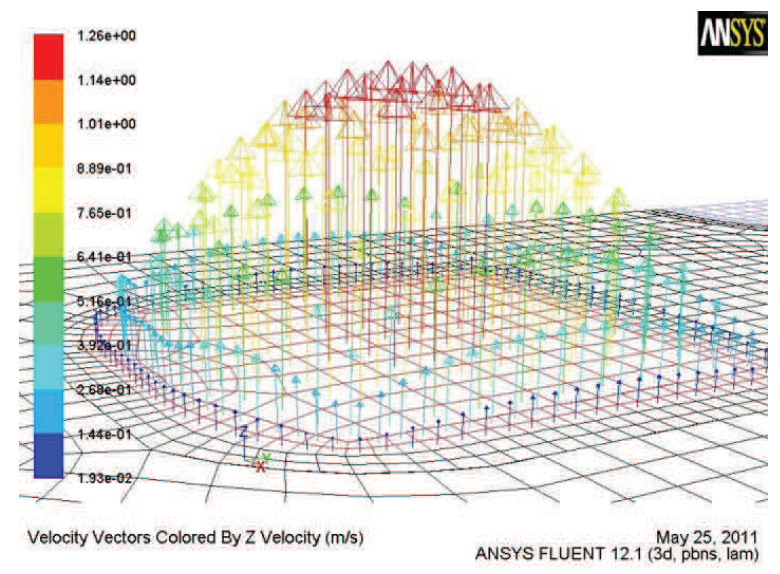

Figure 20 Demonstration of the velocity field at the channel output with laminar flow

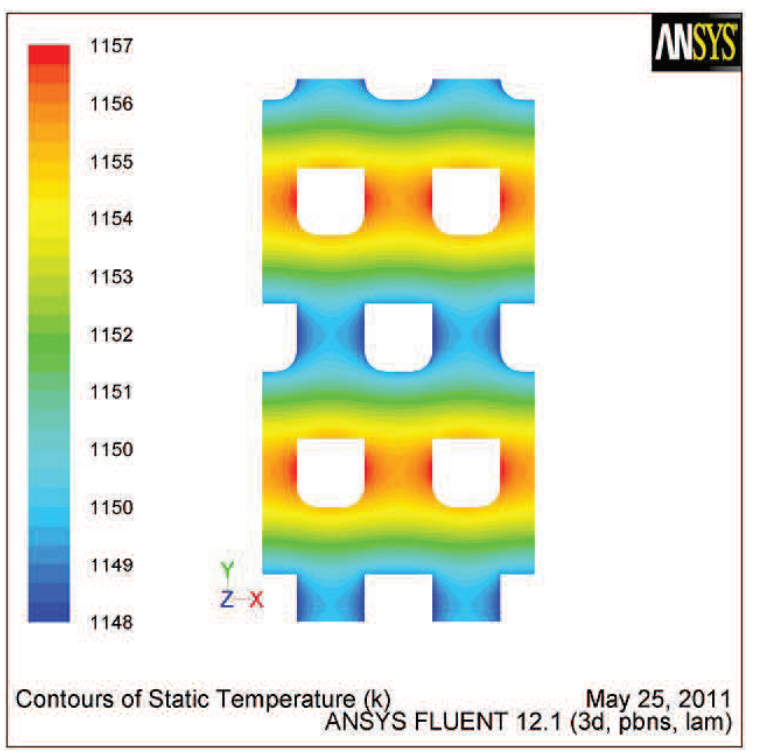

Figure 21 Demonstration of the temperature field in the material of the exchanger

\section{Materials}

We assume to use the following materials for heat exchangers used in MSR.

\subsection{Material Monicr $[10,11]$}

The material of nickel-molybdenum alloy Monicr Skoda is one of the suitable materials usable for MSR reactors components. It was developed in SKODA NE (Nuclear Engineering). The reason was an impossibility to buy the MSRE operation - tested material by the Haynes company, called Hasteloy N, for a loop to work with fluoride salts. The Haynes company offered: delivery term 3-4 years, minimum 10 tons from each assortment. (This still applies nowadays, 20 years later). Skoda NE elaborated a project assignment to develop a new material with a composition outside the patent rights of producers (composition, leguras, minimum impurities, melting in a vacuum furnace under defined pressure conditions in both melting and casting chambers into moulds, heat treatment options, etc.), within the MSR nationwide task, solved by a consortium of resolvers (Faculty of Nuclear Sciences and Physical Engineering - Czech Technical University, Nuclear Physics Institute - The Academy of Sciences of the Czech Republic, Nuclear Research Institute Rez, SKODA NE). Melting happened in Kovohute Rokycany (300 to $500 \mathrm{~kg}$ ) from 1996. Certain works, paid by SKODA NE, were assigned to SKODA Research within the SKODA concern and according to its practice; mainly such works, which Skoda Research was equipped for (determination of material composition of both composites and final alloy, measurement of alloy properties on Setaram device, supervision over requirements during melting, and, later on, also assistance in case of material cracking). That happened already during the first melting, when required vacuum was not abided and nitrogen was detected in the material. Ingots were re-forged into broad strips and stick in SKODA Forge (at present, Skoda Steel Ltd.). Rolling billets in Skoda gave rise to cracks at the strips edges. It was associated with transforming large grains in microstructure, and elicited a research of Monicr recrystallization powers after high-temperature forming, where the Technical University Ostrava was participated within the framework of this assignment. Problems with sheets rolling were resolved in Bergakademie Freiberg, which uses a rolling mill equipped by the latest pressure and temperature meters. If the material temperature does not drop below a certain value, cracks do not appear. A production of extruded tubes took place in Zelezarny (Steelworks) in Hradek. The University of West Bohemia in Pilsen determined extrusive forces with the help of a technological program DEFORM and Monicr properties and a tube fell out on the very first attempt. The Technical University in Kosice measured Monicr creep properties. Skoda NE verified a good weldability of Monicr by both an electron bean and additional materials under a controlled atmosphere, and they produced a whole range of devices for Nuclear Research Institute Rez and Nuclear Physics Institute - The Academy of Sciences of the Czech Republic. They also produced an autoclave, which functioned for long-term corrosion tests 
of Monicr up to $800{ }^{\circ} \mathrm{C}$. Some corrosion experiments in ampoules made of Monicr alloy in molten fluoride salts (LiF-NaF) under over-project temperatures from $720{ }^{\circ} \mathrm{C}$ up to $780{ }^{\circ} \mathrm{C}$ for 550 hours were carried out in an independent reference laboratory of The Kurchatov Institute in Moscow, within observing corrosion properties of Monicr alloy. Corrosion tests with controlled redox potential were performed as well. Also the Monicr mechanic properties were measured in Kurchatov, before tests, after corrosion tests, and after being irradiated in the reactor in ampoules with salts.

\subsubsection{Mechanic and thermal properties of the Monicr} alloy SKODA NE [10]

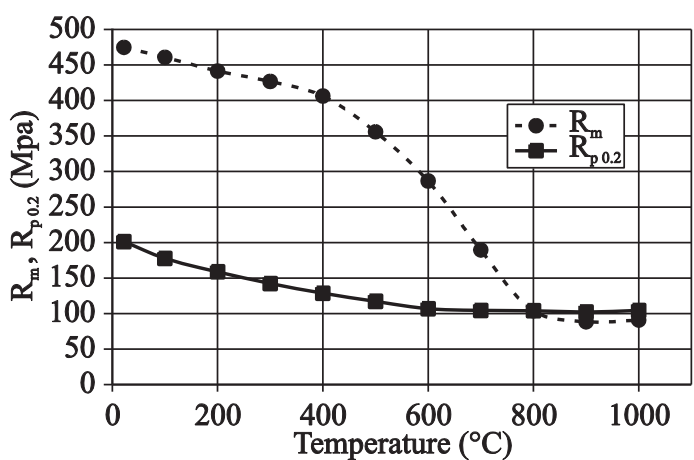

Figure 22 Temperature dependence of tensile strength and yield strength on the Monicr material temperature

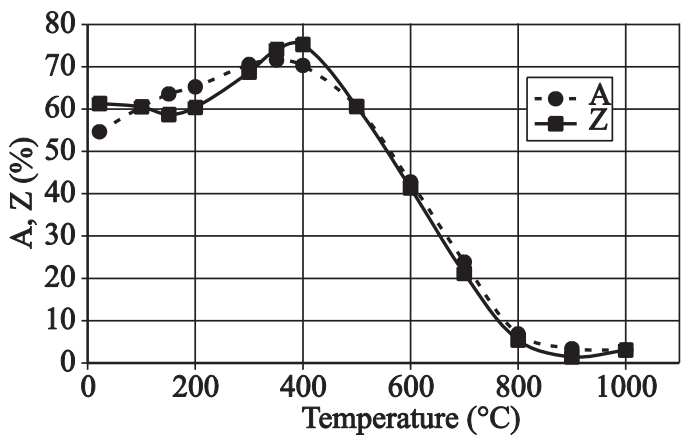

Figure 23 Ductility and contractions at higher temperatures of Monicr material

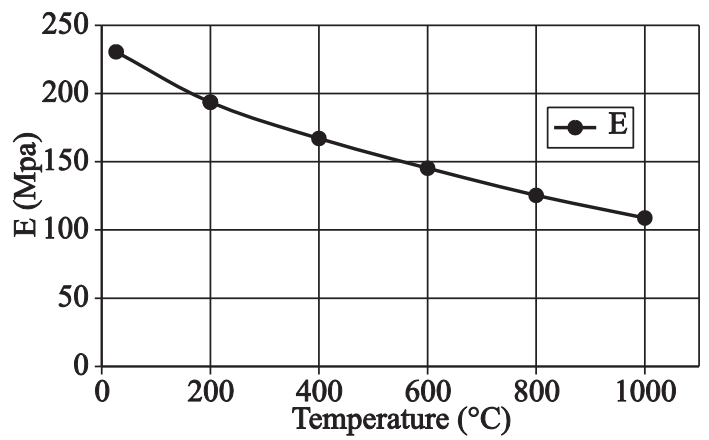

Figure 24 Modulus of elasticity at higher temperatures of Monicr material

The test results proved excellent properties of the Monicr alloy for its use as a construction material for MSR reactors for long-term temperatures up to $720{ }^{\circ} \mathrm{C}$. Monicr has an extreme brittle fracture resistance. After being in liquid nitrogen for 24 hours during testing, Charpy testing equipment could not break the tested units. Material Monicr is usable also for very low temperatures.

The range of melting temperature of the Nickel alloy Monicr $1418-1431{ }^{\circ} \mathrm{C}$.

Table 3 Monicr temperature dependences

\begin{tabular}{|c|c|c|c|c|}
\hline $\mathrm{T}\left({ }^{\circ} \mathrm{C}\right)$ & $\rho$ & $\alpha$ & $\mathrm{c}_{\mathrm{p}}$ & $\lambda$ \\
\hline 20 & 8950 & - & 435 & 13.0 \\
\hline 100 & 8920 & 6.45 & 447 & 14.0 \\
\hline 200 & 8890 & 12.90 & 461 & 15.2 \\
\hline 300 & 8853 & 13.15 & 475 & 16.6 \\
\hline 400 & 8817 & 13.40 & 490 & 18.3 \\
\hline 500 & 8777 & 13.80 & 504 & 20.3 \\
\hline 600 & 8736 & 14.20 & 519 & 22.8 \\
\hline 700 & 8690 & 14.75 & 533 & 25.9 \\
\hline 800 & 8643 & 15.30 & - & - \\
\hline 1000 & 8550 & 15.90 & - & - \\
\hline
\end{tabular}

$k e y$

$\rho\left(k g \cdot m^{-3}\right) \quad$ density

$\alpha\left(10^{-6} \mathrm{~K}\right) \quad$ linear expansion

$c_{p}\left(J \cdot \mathrm{kg}^{-1} \cdot \mathrm{K}^{-1}\right)$ heat capacity

$\lambda\left(W \cdot m^{-1} \cdot K^{-1}\right)$ heat conductivity

$\beta \doteq 3 \cdot \alpha \quad$ volume expansion

\subsection{C/SiSiC Composites. [7]}

The $\mathrm{C} / \mathrm{SiSiC}$ composites were made by the Institute of Structures and Design, German Aerospace Center (DHL), utilizing an experimental process that has been described in a separate papers $[8,9]$. The $\mathrm{C} / \mathrm{SiSiC}$ composites were formed by a Si melt infiltration process into a base carbon fiber material to convert the matrix carbon into $\mathrm{SiC}$ and to fill residual porosity. Some carbon fibers were retained to reinforce the ceramic. The $\mathrm{Si}$ melt infiltration was performed in a furnace at $16500 \mathrm{C}$ under a pressure of $1 \mathrm{mbar}$ with a holding time $45 \mathrm{~min}$. The $\mathrm{C} / \mathrm{SiSiC}$ composites coupons were fabricated and cut from flat plates [8]. Wet chemical analysis found the elemental composition of the ceramic as: $\mathrm{SiC}=69 \mathrm{~m} . \%$ (59 vol.\% ), $\mathrm{Si}=19 \mathrm{~m} . \%$ (22 vol.\%), and $\mathrm{C}=12 \mathrm{~m} . \%$ (19 vol.\%). The carbon fiction remained mostly in a form of the carbon fibers that were remained in the microstructure. Chemical vapor deposites (CVD) pyrolytic $\mathrm{C}$ (PyC) and $\mathrm{SiC}$ coatings were applied by Hyper-Therm HighTemperature Composites, Inc., on several coupons [6]. The $\mathrm{C} / \mathrm{SiSiC}$ composites were first coated in $\mathrm{SiC}$, followed by an overlayer of PyC. 


\section{Fluoride salts}

Fluoride salts represent an interesting material for heat transfer. table 4 shows a comparison with other coolants. The main benefits of fluoride salts are:

- High volume specific heat capacity

- High boiling temperature (for most salts higher than $1400^{\circ} \mathrm{C}$ )

- Low steam pressure

- Melting temperature approx. $400-500^{\circ} \mathrm{C}$

Table 4 Comparison of coolant thermophysical properties with alternative coolants and materials (values at $700{ }^{\circ} \mathrm{C}$, except $290{ }^{\circ} \mathrm{C}$ )

\begin{tabular}{|c|c|c|c|c|c|c|}
\hline material & $\begin{array}{c}\mathrm{T}_{\text {melt }} \\
{ }^{\circ} \mathrm{C} \\
\end{array}$ & $\begin{array}{c}\mathrm{T}_{\text {boil }} \\
{ }^{\circ} \mathrm{C}\end{array}$ & $\begin{array}{c}\rho \\
\mathrm{kg} / \mathrm{m}^{3}\end{array}$ & $\begin{array}{c}\rho c_{\mathrm{p}} \\
\mathrm{kJ} / \mathrm{m}^{3} \mathrm{~K}\end{array}$ & $\begin{array}{c}\lambda \\
\mathrm{W} / \mathrm{m}^{2} \mathrm{~K}\end{array}$ & $\begin{array}{c}v \\
\mathrm{~m}^{2} / \mathrm{s}\end{array}$ \\
\hline flibe $^{a}$ & 459 & 1430 & 1940 & 4540 & 1.0 & 2.9 \\
\hline flinak $^{\mathrm{b}}$ & 454 & 1570 & 2019 & 4060 & 0.60 & \\
\hline Sodium & 97.8 & 883 & 790 & 1000 & 62 & 0.25 \\
\hline Lead & 328 & 1750 & 10540 & 1700 & 16 & 0.13 \\
\hline Helium $^{\mathrm{c}}$ & - & - & 3.8 & 20 & 1.29 & 11 \\
\hline Water $^{\mathrm{c}}$ & 0 & 100 & 732 & 4040 & 1.56 & 0.13 \\
\hline Graphite & - & - & 1700 & 3230 & 200 & - \\
\hline
\end{tabular}

Practically, salts can be worked with under the temperature of $1000{ }^{\circ} \mathrm{C}$ and atmospheric pressure, which represents high safety in comparison with other coolants. Alongside it is possible to transfer high heat outputs at lower volume flows and temperature gradient.

To compare salts used in primary exchangers of the Helix type, we mention their properties for a mean operational temperature.

Table 5 Comparison of salt thermophysical properties for mean operational temperatures $[17,18]$

\begin{tabular}{|c|c|c|c|}
\hline & $\begin{array}{c}\text { LiF-NaF- } \\
\mathrm{BeF}_{2}\end{array}$ & NaF-NaBF & $\begin{array}{c}\mathrm{LiF}_{4}-\mathrm{BeF}_{2^{-}} \\
\mathrm{ThF}_{4}-\mathrm{UF}_{4}\end{array}$ \\
\hline $\mathrm{T}_{\text {average }}{ }^{\circ} \mathrm{C}$ & 685.5 & 532.5 & 661 \\
\hline $\mathrm{T}_{\text {melt }}{ }^{\circ} \mathrm{C}$ & 457 & 384 & 449 \\
\hline$\rho \mathrm{kg} / \mathrm{m}^{3}$ & 2091.2 & 1873.5 & 3312 \\
\hline $\mathrm{c}_{\mathrm{p}} \mathrm{J} / \mathrm{kgK}$ & 2155.7 & 1510 & 1340 \\
\hline$\nu \mathrm{m}^{2} / \mathrm{s}$ & $2.86 \cdot 10^{-6}$ & $7.55 \cdot 10^{-7}$ & $2.62 \cdot 10^{-6}$ \\
\hline$\lambda \mathrm{W} / \mathrm{m}^{2} \mathrm{~K}$ & 0.882 & 0.369 & 1.23 \\
\hline
\end{tabular}

Detailed properties of fluoride salts can be found in the literature $[12,13,14,15,16]$

\section{Conclusions}

This work points to benefits of using helical baffles for shell and tube exchanger, and using a compact plate heat exchanger for high temperature heat transfer.

\footnotetext{
${ }^{\text {a }} \mathrm{Li}_{2} \mathrm{BeF}_{4}$

${ }^{\mathrm{b}} \mathrm{LiF}-\mathrm{NaF}-\mathrm{KF}$

c 7,5 $\mathrm{MPa}$
}

This work also presents an elegant counter-flow solution and its use for nuclear reactors of IV generation. Compact plate heat exchangers with square channels when using graphite composites are applicable for molten salt reactors and chemical industry as well, as graphite composites are resistant when working with fluoride salts, acids and bases.

The production technology for graphite composites usable for working under temperatures of approx. $1000{ }^{\circ} \mathrm{C}$ is mastered $[6,8,9]$. It is necessary to point out that frequently published data do not state the temperature during which they were measured. Heat conductivity depends on the graphite fibers position. The conductivity is proportionally bigger in the paraller position with fibers than in the lateral position. In reality, everyone should appreciate to realize the heat transfer in the direction of carbon fibers, which needs to be kept in mind and pointed out in the composite production. The properties data are often missing. The composition of LSI $\mathrm{C} / \mathrm{C}$ composite is usually well-known. E.g. the ratio of graphite and $\mathrm{SiC}$ is approximately 61:33. Properties of pyrolytic graphite [25] and $\mathrm{SiC}$ [26] have been measured, and The Center for Energy Research, University of California, in San Diego have published them within the framework of the program Advanced Energy Technology Group. In the work [20], the eventual heat conductivity was obtained by a simple multiplication of material mass ratios and their heat conductivities. Individual components are connected by phenolic resin. This connection is made by pyrolysis, when a graphite is extracted from the resin; a porosity and thereby a stauchness of joints depends on the graphite yield from the resin. Physical properties of joints demonstrate almost identical values like the original material.

A worse situation is with metal materials. Currently the corrosion - resistant materials are limited by the temperature of approximately $720^{\circ} \mathrm{C}$ for a long-term run. Since the proven material Hasteloy $\mathrm{N}$ and its modifications are not available, we included a brief description of the Monicr SKODA material development, which is a proper substitution of Hasteloy N. For the IV generation reactors, higher operational temperatures are considered, as well as the facility lifespan of 50 years, or even 60 years according to some studies. In 2002-2003, materials mentioned in [6] were chosen in [23] for corrosion tests in FLiNaK salts as perspective materials for higher temperatures. Their properties adopted from producers are stated there as well. We show in figure 25 temperature stress dependences for individual materials. In table 6 there are times for three higher temperatures and stress, when due to creep the material ruptures. We can easily identify that materials mentioned in this table are not suitable for a long-term run and higher tensile strength. Perhaps the material $\mathrm{Nb}+1 \% \mathrm{Zr}$, which is not tested and probably is very expensive, would comply. There have not been any information about other materials so far. The present state in projects is solved, e.g. pressure tank is cooled from inside to the temperature, during which it can handle the operation, and that seems to be a great complication.

The most suitable salts for energetic applications have been chosen lately. In [15] there are chloride salts and 
nitrides chosen as coolants for solar power engineering, besides fluoride salts (FLiBe, FLiBeNa, FLiNaK, NaF$\mathrm{NaBF}_{4}$ ). All available measured properties are summarized and an accuracy of both measurements and properties approximation is determined. However, the surface tension is missing. Choride salts are used for cleaning fuel mass from lanthanides (fission products) in [24]. Nusselt criteria are acknowledged in [16]. We reccommend a choice of properties from later works for further calculations.

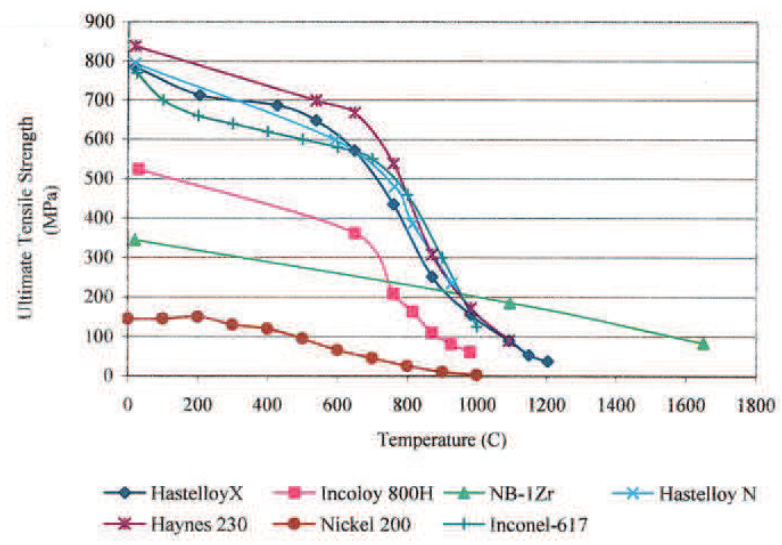

Figure 25 Ultimate tensile strength as a function of temperature of the alloys selected for corrosion tests (sources: [27, 28, 29, $30,31,32,33,34])$

Table 6 Stress rupture data of several relevant alloys. *Values approximated from graph. (Source: [32, 33, 34])

\begin{tabular}{|c|c|c|c|}
\hline \multirow{2}{*}{} & \multicolumn{3}{|c|}{ Hours to Rupture } \\
\cline { 2 - 4 } & $\begin{array}{c}760^{\circ} \mathrm{C} \\
103 \mathrm{MPa}\end{array}$ & $\begin{array}{c}871^{\circ} \mathrm{C} \\
31 \mathrm{MPa}\end{array}$ & $\begin{array}{c}982^{\circ} \mathrm{C} \\
14 \mathrm{MPa}\end{array}$ \\
\hline Inconel-617 & $20000^{*}$ & $30000^{*}$ & $7000^{*}$ \\
\hline Haynes-230 & 8200 & 6500 & 5000 \\
\hline Hastelloy-X & 900 & 5000 & 2100 \\
\hline Incoloy-800H & 130 & 1200 & 920 \\
\hline 304 Stainless Steel & 10 & 100 & 72 \\
\hline
\end{tabular}

It is also necessary to point out that although until recently proposed mixtures such as $\mathrm{NaF}_{-} \mathrm{ZrF}_{4}$ (50-50) have the biggest solubility $\mathrm{XF}_{3}(\mathrm{X}$ is $\mathrm{Pu}$ and lanthanides fission products), but the criticality in both thermal and fast area of neutron spectrum is not reached, even with the solubility of only $\mathrm{PuF}_{3}$ [35]. The $\mathrm{PuF}_{3}$ concentrations needed to reach the criticality $\left({ }_{\mathrm{kef}}=1\right)$ are larger than the limit of $\mathrm{PuF}_{3}$ solubility in a given salt, in the whole range of the ratio moderator - fuel salt. A problem with hard radiation gamma (harder than well-known $\mathrm{Co}^{60}$ has) is not dealt with in rubidium mixtures. RB has two stable isotopes. By $(n, \gamma)$ reaction, from $\mathrm{Rb}^{85}(72,17 \%)$ arises $\mathrm{Rb}^{86}$, which with a radioactive half-time $T_{1 / 2}=18.65 \mathrm{~d}$ produces gamma radiation with energy $1,078 \mathrm{MeV}$. From the second isotope of $\mathrm{Rb}^{87}(27.83 \%)$ arises radioactive $\mathrm{Rb}^{88}$, which with $\mathrm{T}_{1 / 2}=17,7 \mathrm{~m}$ produces gamma radiation with energies $1,836 \mathrm{MeV}$ a $0,898 \mathrm{MeV}$ [36]. It is necessary to comprehensively consider all the limitations. A large source of gamma radiation during the reactor operation will lead to a radiation damage of materials in a primary circuit and will have an impact on their lifespan.

\section{Acknowledgements}

This work has been supported by the SUSEN Project CZ.1.05/2.1.00/03.0108 realized in the framework of the European Regional Development Fund (ERDF) and student project SGS-2014-070 (Zvyšování účinnosti, spolehlivosti a životnosti energetických strojů a zařízení $3)$.

\section{References}

1. G.F. Hewitt, G.L. Shires, T.R. Bott: Process Heat Transfer (CRC Press, Boca Raton, New York,1994)

2. G.F. Hewitt (Executive editor): Heat Exchanger Desing Handbook 2008, Part 3, Thermal and Hydraulic Design of Heat Exchangers. See B. Dzyubenko, G. Draisler: 3.23.1-4 (p.1-15)

3. P. Stehlík: Various Ways to Improve Heat Transfer as a Contribution to Enviramental Design, (VUT Brno)

4. P. Stehlík, J. Kohoutek, J. Němčanský: Tepelné pochody, Výpočet výměníku tepla (VUT Brno, 1991)

5. J.R. Tallacson: Thermal Radiation Transfer of Afterheat in MSBR Heat Exchanger (ORNL-TM3145, 1971)

6. L.Ch. Olson: Materials Corrosion in Molten LiFNaF-KF Eutectic Salt (Dissertation for degrese of Doctor of Philosofy (Nuclear Engineering), University of Wisconsin - Madison)

7. P.F. Peterson, Ch.W. Fosberk, P.S. Pickard: Advanced CSiC composites for high temperature nuclear heat transport with helium, molten salts. Second Information Exchanger Meeting on Nuclear Production of Hydrogen (ANL Illinois, USA, October 2003)

8. J. Schmidt, M. Schieffele, M. Crisppa, P. Peterson et all., International Journal of Applied Ceramic Technology, 8 p. 1073 - 1086.

9. J. Schmidt: Potencial Application for Liquid Silicon Melt Infiltrated (LSI) Composite to the HighTemperature Sulfur-Iodin (S-I) Process (Visiting Scholar at University of California, Berkeley, October- December 2006)

10. P. Hosnedl, O. Blahut, R. Jakš a kol.: Experimentální ověrení vybraných variant transmutační technologie a vydání podkladu pro projektováni základních komponent demonstračníhé rektoru LA-10, (2003)

11. P.Hosnedl et all.: MOST WP5 - Rewiew and Analysis of the Structural Materials (June 2003, technical report SŠKODA JS a.s. Ae 11152/Dok)

12. V.M. Novikov, V.V. Ignatiev, V.I. Fedulov, V.N. Cerednikov: Židkosolevye JaEU: Perspektivy $i$ problemy (Moskva, Energoizdat, 1990.)

13. V. Valenta, Návrh vhodné směsi fluoridových soli pro transmutor PuF3 a vyššich aktinidů (Ústav jaderné fyziky AV, Report NPI Řež, TECH-03/2005)

14. M.S. Sohal, M.A. Ebner, P. Sabarwall, P. Sharpe, Engineering Database of Liquid Salt Thermophysical and Thermochemical Properties (Idaho, Idaho National Laboratory Idaho Falls, 2010, INL/EXT-1018297) 
15. R. Serano-Lopez, J. Fradera, S. Cuesta-Lopez, Chemical Engineering and Processing 73, p. 87 102 (2013)

16. O. Beneš, M. Beilmann, R. Konings, Journal of Nuclear Materials, Volume 405, Issue 2, 15 (October 2010)

17. P. Fedor, Návrh a výpočet výměníku tepla $v$ primárním okruhu MSR se šroubovitými přepážkami (University of West Bohemia in Pilsen 2014)

18. D. Okresa, Návrh a výpočet výměníku tepla $v$ primárním okruhu MSR se šroubovitými přepážkami (University of West Bohemia in Pilsen 2014)

19. J. Makovec: Návrh výměníku tepla z grafitových kompozitů, deskový výměník (University of West Bohemia in Pilsen 2011)

20. J. Jílek, Návrh deskového výměníku tepla $z$ grafitových kompozitů (University of West Bohemia in Pilsen 2011)

21. W.M. Rohsenow, J.P. Hartnett, Handbook of Heat Transfer (New York, McGraw - Hill Book Company, 1973)

22. http://ansys.com/Support/Documentation

23. Generation IV Roadmap Crosscutting Fuels and Materials R\&D Scope Report, GIF-010-00, 2002

24. A. Bejan, A.D. Kraus, Heat Trensfer Handbook, chapter 5 (John Wiley a sons, Inc., New, Jersey, 2003)

25. P.J. Karditsas, M. Baptiste, Thermal and Structural Properties of Fusion related Materials (Center for Energy Technology Group, San Diego)

26. http://aries.ucsd.edu/LIB/PROPS/PANOS/c.html

27. High Temp Metals Inc. "Hastelloy X technical data," [Online],

Available: www.hightempmetals.com/techdata/hitem pHastXdata.php

28. Special Metals Corporation, "Nickel 200 \& 201," [Online].

Available: http://www.specialmetals.com/documents /Nickel\%20200\%20\&\%20201.pdf

29. Special Metals Corporation, "Incoloy Alloy 800," [Online],

Available: http://www.specialmetals.com/documents /Incoloy\%20alloy\%20800.pdf

30. J. Lambert, Properties and Selection: Nonferrous Alloys and Special-Purpose Materials, Vol. 2 (1990)

31. Haynes International, "High Performance Alloys Technical Information: Hastelloy N Alloy," [Online]. Available: http://www.haynesintl.com/pdf/h2052.pdf

32. Haynes International, "High Temperature Alloys: Haynes 230 Alloy," [Online], Available: http://www.haynesintl.com/pdf/h3000.pdf

33. Special Metals Corporation, "Inconel Alloy 617," [Online],

Available: http://www.specialmetals.com/documents /Inconel alloy 617.pdf

34. High Temp Metals, Inc. "Alloy 800/800AT/800H Technical Data," [Online], Available: http://www.hightempmetals.com/techdata /hitempIncoloy800data.php

35. V. Valenta, Modelování a měření v energetice (Nečtiny 2010)
36. Nuclides and Isotopes (Chart of the Nuclides), Sixteen Edition, Revised 2002. Copyright 2002, KAPL, Inc. Lockhead Martin, www.ChartOfThe Nuclides.com 